\title{
Enzootic Ataxia in a Norwegian Red Deer Herd
}

\author{
By K. Handeland and A. Flåøyen \\ National Veterinary Institute, Oslo, Norway
}

In the 1960 s, a disease characterized clinically by ataxia and posterior paresis that had for a long time been recognised in park herds of red deer (Cervus elaphus) in Britain, and in park and wild red deer in Germany, was shown to be associated with demyelination in the spinal cord (Barlow \& Butler 1964, Terlecki \& Done 1964, Knösel \& Schulz 1968). Some of the cases also showed nerve cell degeneration and necrosis in the brain tissue. Later, enzootic ataxia was reported in deer farms in New Zealand (Wilson et al. 1979), Australia (Peet \& Hepworth 1993), China (Yoshikawa et al. 1996) and Germany (Geisel et al. 1997). The disease occurs in young adult deer. The aetiology is considered multifactorial, but copper $(\mathrm{Cu})$ deficiency appears a central factor, and the disease can be efficiently prevented through $\mathrm{Cu}$ supplementation (Wilson et al. 1979). In New Zealand, $\mathrm{Cu}$ deficiency has also been suggested as a cause of osteochondrosis in farmed red deer calves (Thompson et al. 1994, Audigè et al. 1995).

This paper reports the occurrence of enzootic ataxia in a small red deer herd located on a dairy farm in the municipality of Ølen, Hordaland county, Norway. The herd, comprising about 15 animals, was established in the late 1980s based on locally wild-captured animals. The animals grazed unfertilised, semi-cultivated pasture in a 10 hectare enclosure. From
October to April they also had access to silage ad libitum, and, once a week, the animals were given a mineral mixture produced for cattle and goat (Felleskjøpet) mixed with concentrates. The mineral mixture contained $600 \mathrm{mg} \mathrm{Cu}$ per kilogram.

During winter 1996/97 a 1.5-year-old female developed signs of posterior locomotor disturbances. The condition remained stable for about 8 months after which the animal was destroyed without veterinary inspection. In November 1997 a 2.5-year-old female showed signs of hind limb weakness and unsteadiness while running. Signs progressed, and the animal was euthanized 1 month after onset of disease. Its head, cervical columna and samples of liver and blood were available for laboratory examination.

The skull was split in the sagittal plane and the cervical vertebral column was opened from the dorsal. No gross lesions could be found on the brain and spinal cord, and the organs were fixed in $10 \%$ buffered formalin. After fixation, tranverse tissue blocks of the cerebral hemispheres, pons, cerebellum and medulla oblongata and 2 tranverse tissue blocks per segment of the cervical spinal cord were embedded in paraffin, cut at $5 \mu \mathrm{m}$, and stained with haematoxylin and eo$\sin (\mathrm{HE})$ for histopathological examination. Selected sections were stained with luxol fast blue. The concentration of $\mathrm{Cu}$ in the liver tissue 


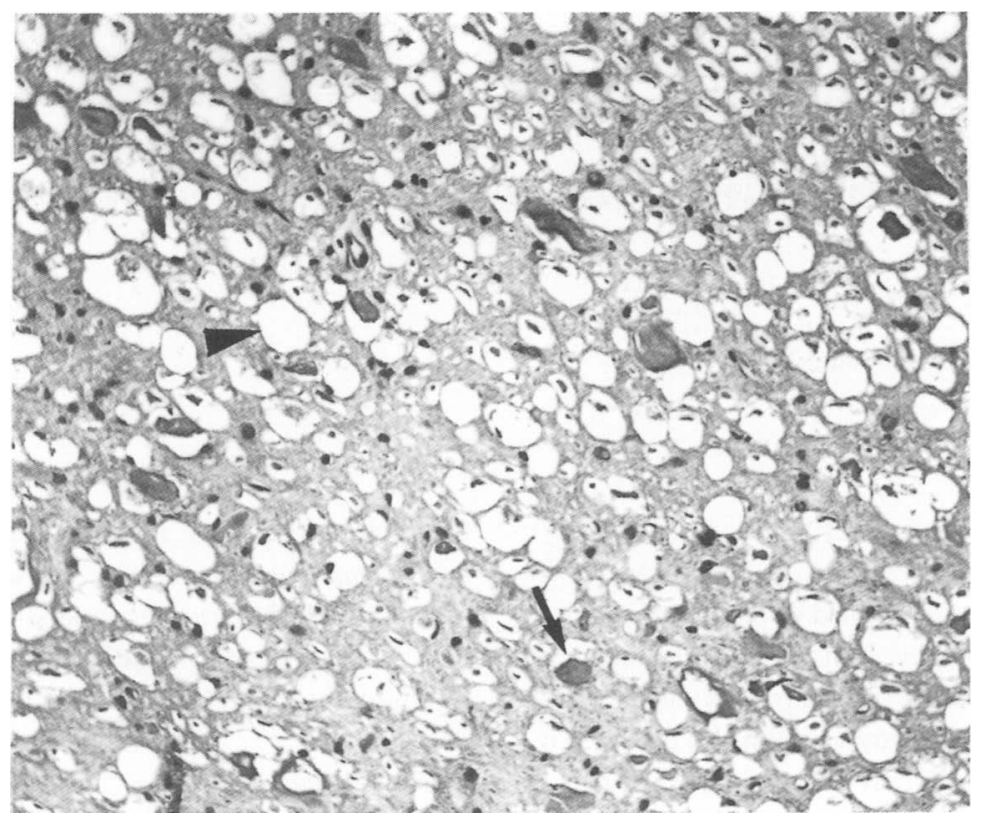

Figure 1. Cross section of the cervical spinal cord. Deficit of stainable myelin, and vacuoles with swollen (arrow) or disintegrated (arrowhead) axons and scattered macrophages. HE $\times 200$.

and serum were measured using atomic absorption spectroscopy (Jorhem \& Engman 1996). Histopathological examination revealed bilaterally symmetrical demyelination and axon degeneration in the ventral and lateral columns of the cervical spinal cord (Fig. 1). Vacuoles or distended myelin sheats surrounding swollen or disintegrated axons and scattered macrophages frequently gave affected areas a spongy appearence. Similar lesions also occurred in white matter of the medulla oblongata, but no consistent histological findings could be detected elsewhere in the brain tissue. The concentrations of $\mathrm{Cu}$ in the liver tissue and blood serum were $47 \mu \mathrm{mol} / \mathrm{kg}$ wet matter basis (WMB) and $6.3 \mu \mathrm{mol} / 1$ respectively.

Our diagnosis of enzootic ataxia was made on the basis of typical clinical signs and histopathological spinal cord lesions (Barlow \& Butler
1964, Terlecki \& Done 1964, Knösel \& Schulz 1968), combined with abnormally low $\mathrm{Cu}$ levels in the liver and serum.

The liver is the central storage organ for $\mathrm{Cu}$ in the body and therefore analysis of liver samples gives the best indication of the $\mathrm{Cu}$ status (Grace 1983). The level of $\mathrm{Cu}$ in serum is controlled by homeostatic mechanisms and can be normal also when liver $\mathrm{Cu}$ levels are low. Thus, the level of $\mathrm{Cu}$ in serum declines only after the $\mathrm{Cu}$ concentration in the liver has been depleted (Mackintosh et al. 1986). The $\mathrm{Cu}$ liver concentration found in our animal was below the concentration of $100 \mu \mathrm{mol} / \mathrm{kg}$ WMB regarded as deficient in farmed deer, and lower than 60 $\mu \mathrm{mol} / \mathrm{kg}$ considered the "critical» concentration below which enzootic ataxia may occur (Clark \& Hepburn 1986, Mackintosh et al. 1986). The serum $\mathrm{Cu}$ concentration found was 
below $8 \mu \mathrm{mol} / 1$, which is regarded as indicative of $\mathrm{Cu}$ deficiency following liver depletion (Clark \& Hepburn 1986, Mackintosh et al. 1986).

$\mathrm{Cu}$ deficiency can occur as a result of ingesting pasture containing an inadequate level of $\mathrm{Cu}$ (simple deficiency), or as a result of high levels of molybdenum, sulphur, iron, and cadmium in the diet reducing the absorption or availability of $\mathrm{Cu}$ (induced $\mathrm{Cu}$ deficiency) (Grace 1983). A more complete evaluation of causes requires pasture and soil analyses that were not carried out in our study. However, the reported cases occurred during winter, when $\mathrm{Cu}$ liver concentrations in farmed deer have been found to decrease due to low $\mathrm{Cu}$ contents in pasture (Mackintosh et al. 1986). In addition, feeding on silage during winter may have contributed to $\mathrm{Cu}$ deficiency, as this is usually made from rapidly growing spring grass which tends to be very low in $\mathrm{Cu}$ (Mackintosh 1998).

\section{References}

Audigè L, Wilson PR, Morris RS, Davidson GW: Osteochondrosis, skeletal abnormalities and enzootic ataxia associated with copper deficiency in a farmed red deer (Cervus elaphus) herd. $\mathrm{N}$ Z. Vet. J. 1995, 43, 70-76.

Barlow RM, Butler EJ: An ataxic condition in red deer (Cervus elaphus). J. Comp. Path. 1964, 74, 519-529.

Clark RG, Hepburn JD: Deer liver and serum copper levels. Surveillance 1986, 13, 11-14.
Geisel O, Betzl E, Dahme E, Schmal W, Hermanns W: Enzootic spinal ataxia of farmed fallow and red deer in Southern Bavaria/Germany. Tierärztl. Prax. 1997, 25, 598-604.

Grace ND: Copper $(\mathrm{Cu})$. In: Graze ND (ed): The mineral requirements of grazing ruminants. $\mathrm{N} Z$. Soc. Anim. Prod. 1983, 9, 56-66.

Jorhem L, Engman J: Determination of lead, cadmium, zinc, copper and iron in foodstuffs by atomic absorption spectrophotometry after microwave digestion: NMKL Collaboratory study. 1996. Statens Livsmedelverk, Sverige.

Knösel H, Schulz L-C: On the pathogenesis of endemic paresis (lameness of the hip) in red deer. Berl. Münch. Tierärztl. Wschr. 1968, 8, 92-96.

Mackintosh CG: Deer health and disease. Acta Vet. Hung. 1998, 46, 381-394.

Mackintosh CG, Wilson PR, Beatson NS, Turner K, Johnstone P: Preliminary report of the liver:serum copper relationship in red deer. Proc. Deer Course for Veterinarians 1986, 3, 156-164.

Peet RL, Hepworth K: Enzootic ataxia in red deer, Cervus elaphus. Austral. Vet. J. 1993, 70, 395396.

Terlecki S, Done JT: Enzootic ataxia of red deer. Brit. Vet. J. 1964, 120, 311-321.

Thompson KG, Audigè L, Arthur DG, Julian AF, Orr $M B$, McSporran KD, Wilson PR: Osteochondrosis associated with copper deficiency in young farmed red deer and wapiti $x$ red deer hybrids. $\mathrm{N}$ Z. Vet. J. 1994, 42, 137-143.

Wilson PR, Orr MB, Key EL: Enzootic ataxia in red deer. N Z. Vet. J. 1979, 27, 252-254.

Yoshikawa H, Seo H, Oyamada Ta, Ogasawara T, Oyamada To, Yoshikawa T, Wei X, Wang S, Li Y: Histopathology of enzootic ataxia in sika deer (Cervus nippon Temminck). J. Vet. Med. Sci. 1996, 58, 849-854.

(Received February 10, 2000; accepted March 20, 2000).

Reprints may be obtained from: K. Handeland, Section of Wildlife Diseases, National Veterinary Institute, P.O.Box 8156 Dep., N-033 Oslo, Norway. E-mail: kjell.handeland@vetinst.no. 